\title{
Cyclosporin A-Induced New Cementum Formation: A Morphometric Evaluation in the Periapical Region of Rats
}

\author{
Luis Carlos SPOLIDORIO ${ }^{1}$ \\ Denise Madalena Palomari SPOLIDORIO² \\ Marinella HOLZHAUSEN² \\ Carlos Augusto NASSAR ${ }^{2}$ \\ Patricia Oehlmeyer NASSAR ${ }^{2}$ \\ ${ }^{1}$ Department of Oral Pathology and ${ }^{2}$ Department of Periodontology, School of Dentistry of Araraquara, \\ State University of São Paulo, Araraquara, SP, Brazil
}

\begin{abstract}
Cyclosporin A (CsA) is a potent immunosuppressor used in organ transplantation and in the management of various autoimmune diseases. Recent studies have shown that CsA stimulates deposition of cementum on root surfaces. The aim of this study was to evaluate the periapical cementum thickness and the apical foramen width in CsA-treated rats. Rats weighing $50 \mathrm{~g}$ were treated with a daily injection of $10 \mathrm{mg} / \mathrm{kg}$ body weight of CsA in the chow for 60 days. The cementum of the mandibular 1 st molars was histologically and morphometricaly examined by analysis of 5 - $\mu$ m-thick serial buccolingual paraffin sections stained with hematoxylin and eosin. Histometric and stereologic analyses revealed the presence of large amounts of cementum in all root surfaces, particularly abundant in the periapical region and obliterating the foramen. The volume density of cementoblasts did not increase. Five to 90 days after the termination of CsA therapy, there was no reduction of cementum thickness. These results suggest that cementum deposition is not reversible after cessation of CsA treatment.
\end{abstract}

Key Words: Cyclosporin A, adverse effects, new cementum formation, etiology, animal studies.

\section{INTRODUCTION}

Cyclosporin A (CsA) is a polypeptide composed of 11 amino acids (MW=1202,6) used as a widely spread immunosuppressive drug to prevent organ transplant rejection and also in the management of various pathological conditions. Among the immune system diseases treated with this drug are Behçet's disease, intraocular inflammatory disease, ocular cicatricial pemphigoid, rheumatoid arthritis, psoriasis, bulbous pemphigoid, pemphigus, and other dermatological diseases $(1,2)$. CsA binds calmodulin and cytoplasmatic receptors called cyclophilins, blocking interleukin-2 (IL-2) synthesis by CD4 lymphocytes and promoting immune response suppression. On the order hand, CsA induces an increased production of transforming growth factor- $\beta$ (TGF- $\beta$ ), a potent inhibitor of IL-2-stimulated T-cell proliferation and of the generation of antigen-specific cytotoxic $T$ lymphocytes (3-6). Various side effects associated with CsA treatment have been described, including nephropathy, hypertension, hepatotoxicity, neurotoxicity, hypertricosis and thromboembolic complications. It is well established that CsA causes gingival overgrowth, bone loss and induces cementum deposition (7-14). It has been shown that CsA administrated orally to rats induces abundant new cementum formation with functionally inserting collagen fibers $(12,13)$. New cementum is deposited on the afibrillar extrinsic fiber cementum, mainly on the cervical third of the roots, as irregular layers, spurs of various sizes and shapes, or in both configurations. Ayanoglou and Lesty (12) showed that

Correspondence: Prof. Dr. Luís Carlos Spolidorio, Departamento de Patologia, Faculdade de Odontologia de Araraquara, UNESP, Rua Humaitá, 1680, caixa postal 331, 14801-903 Araraquara, SP, Brasil. Tel: +55-16-201-6479. Fax: +55-16-222-4823. e-mail: lcs@foar.unesp.br 
the deposited new cementum is not reversible after cessation of CsA treatment. The purpose of the present study was to further explore histometrically and stereometrically the effects of CsA therapy on new cementum formation in the periapical region of rat molars.

\section{MATERIAL AND METHODS}

Eighty male Wistar rats (Rattus norvegicus albinus), weighing approximately 50 g were randomly assigned to 8 groups $(\mathrm{n}=10)$. Seven groups were treated subcutaneously with $10 \mathrm{mg} / \mathrm{kg}$ body weight/day of CsA (Sandimmun, Novartis, Basel, Switzerland) during 60 days. The concentration and administration route used in this study provide plasma peak and trough levels of 1000 and $750 \mathrm{ng} / \mathrm{mL}$, respectively (15). The remaining 10 animals were injected similarly with saline and used as controls. The rats were weighed once a week in order to adjust the dose of CsA. After 60 days, all treated animals presented clinically evident gingival overgrowth involving all teeth. The control group and one of the groups treated with CsA (group 0 day) were killed after 60 days of CsA therapy. The other 6 groups were killed 5, 10, 15, 30, 60 and 90 days after the CsA therapy discontinued. The mandibles was carefully removed and fixed in $10 \%$ formalin for $48 \mathrm{~h}$ and decalcified in $5 \%$ EDTA (pH 7.2) at $4^{\circ} \mathrm{C}$ for about 3 months. Six-micrometerthick paraffin-embedded sections were made on the buccolingual aspects of the left and right 1st molars and stained with hematoxylin and eosin. Each mandibular 1st molar had a mesiodistal width of about $1 \mathrm{~mm}$, thus providing nearly 150 six-micrometer-thick sections.

\section{Histometry}

Linear measurements were made with a Zeiss microscope (Carl Zeiss, Jena GmbH, Germany) at X12.5 magnification and using SigmaScan Pro image analysis software (Mocha, Jandel Scientific, San Rafael, CA, USA). In each mandibular first molar, 10 measurements were made in sections obtained at $60-\mu \mathrm{m}$ intervals. Statistical analysis was based on the mean value from each animal, which was calculated from the 30 measurements obtained from the periapical foramen of the right and left 1st molars. Figure 1 shows the areas of linear measurements. Results were expressed in $\mu \mathrm{m}$. Linear measurements were done at X40 magnification.

\section{Stereology}

Volume density of cementoblasts (Vc), collagen fibers (Vf) and other structures (Vo), i.e., blood vessels and unidentified structures, were estimated to the principles established by Delesse (16) and that were applied to histology by Weibel (17). For each animal, a total of 400 points were counted in the periapical region. Counting was performed with Zeiss microscope (Carl Ziess), using oil immersion at 1000 magnification. A square lattice of 25 test points was projected into the ocular microscope with the use of microvid system that connected the microscope to a computer. For each animal, 16 sections were analyzed ( 8 from the left molar and 8 from the right molar), and 25 points were counted in each section. Vc, Vf and Vo were expressed as percentages of the total points counted.

\section{Statistical Analysis}

Measurements were expressed as means and standard deviation. Data were analyzed statically by ANOVA. Student's t-test was used to compare differences between groups.

\section{RESULTS}

\section{Light Microscopy}

In the control rats, the cementum covered the root dentin of the mandibular first molar. Cellular cementum covered the apical root third. In some

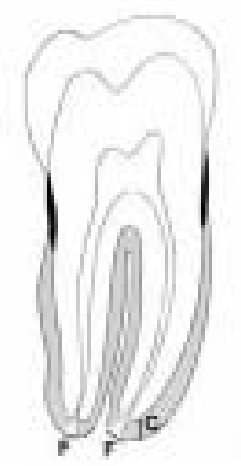

Figure 1. Schematic illustration showing the regions where linear measurements were made. $\mathrm{F}$ is the apical foramen and $\mathrm{C}$ is the cementum thickness. 
segments, the cementum consisted of two or more layers. The external layer showed a striated structure and presented suggestive images of inclusion of collagen fibers. The cementoblats situated close to the cementum surface in the periodontal ligament and constituted ovoid or round, plump cells with a basophilic cytoplasm. These cells were present singly or in groups of up to 4 cells. The cementocytes were present in lacunas inside the cementum.

After 60 days of CsA therapy, all rats showed gingival overgrowth and alveolar bone loss. Its occurrence did not vary between rats of the same group. The

Table 1. Linear measurements $(\mu \mathrm{m})$ of periapical cementum thickness and apical foramen width of control rats, rats sacrificed after 60-day CsA therapy (0 day) and rats sacrificed 5, 10, 15, 30, 60 and 90 days after cessation of CsA therapy.

\begin{tabular}{lcc}
\hline Group & $\begin{array}{c}\text { Cementum } \\
\text { thickness }\end{array}$ & $\begin{array}{c}\text { Apical } \\
\text { foramen width }\end{array}$ \\
\hline Control & $9.5 \pm 5$ & $0.049 \pm 0.002$ \\
60-day CsA therapy - 0 day & $14.2 \pm 7^{1}$ & $0.024 \pm 0.002^{2}$ \\
CsA + 5 days & $14.4 \pm 5^{1}$ & $0.029 \pm 0.005^{2}$ \\
CsA + 10 days & $15.2 \pm 5^{1}$ & $0.028 \pm 0.003^{2}$ \\
CsA + 15 days & $14.5 \pm 5^{1}$ & $0.023 \pm 0.007^{2}$ \\
CsA + 30 days & $16.1 \pm 7^{1}$ & $0.025 \pm 0.005^{2}$ \\
CsA + 60 days & $14.7 \pm 3^{1}$ & $0.028 \pm 0.003^{2}$ \\
CsA + 90 days & $14.4 \pm 5^{1}$ & $0.026 \pm 0.002^{2}$ \\
\hline
\end{tabular}

${ }^{1}$ Statistically significant difference from control $(\mathrm{p}<0.05)$. ${ }^{2}$ Statistically significant differences from control $(\mathrm{p}<0.05)$. cementum of the mandibular molars showed evident enlargement in all test animals. The cementum layer was thicker in the apical root third, and was characterized by presenting an amorphous material containing incremental lines and cementocytes. The periapical foramen diameter decreased and was filled with cementum in most cases. When CsA therapy was discontinued, no decrease of cementum volume was observed. After 90 days, the cementum was still slightly larger in CsAtreated animals compared to the control animals.

\section{Histometric Findings}

Table 1 shows the linear measurements of the periapical cementum thickness, as well as, the apical foramen width. After 60 days of CsA therapy, the cementum measurements were $33 \%$ larger than that of the control while the measurements of the periapical foramen were half normal. After CsA therapy was discontinued, the cementum and periapical foramen measurements remained unchanged in all periods.

\section{Stereometric Findings}

The volumetric density of cementoblasts $(\mathrm{Vc})$, collagen fibers (Vf) and other structures (Vo) were expressed as percentages. In the control animals, the values were 5.4, 66.01 and 31.59 for cementoblasts, collagen fibers others structures, respectively. After 60-day CsA therapy, there was no increase in the number of cementoblasts. Ninety days after cessation of CsA therapy, the percentage of cementoblasts was similar to that found after 60-day CsA therapy (Table 2).
Table 2. Volumetric densities (\%) of cementoblasts (Vc), collagen fibers (Vf) and other structures (Vo) in the periapical root third of control rats, rats sacrificed after 60-day CsA therapy (0 day) and rats sacrificed 5, 10, 15, 30, 60 and 90 days after cessation of CsA therapy.

\begin{tabular}{lccc}
\hline Group & Vc & Vf & Vo \\
\hline Control & $5.4 \pm 0.45$ & $66.01 \pm 0.88$ & $28.59 \pm 0.76$ \\
60-day CsA therapy - 0 day & $6.0 \pm 0.56$ & $68.67 \pm 0.91$ & $25.33 \pm 0.65$ \\
CsA + 5 days & $5.9 \pm 0.71$ & $65.97 \pm 0.78$ & $28.13 \pm 0.74$ \\
CsA + 10 days & $6.1 \pm 0.49$ & $66.33 \pm 0.77$ & $27.57 \pm 0.86$ \\
CsA + 15 days & $6.3 \pm 0.83$ & $65.41 \pm 0.85$ & $28.29 \pm 0.78$ \\
CsA + 30 days & $5.8 \pm 0.47$ & $69.73 \pm 1.10$ & $24.47 \pm 0.92$ \\
CsA + 60 days & $5.3 \pm 0.74$ & $69.68 \pm 0.76$ & $25.02 \pm 0.86$ \\
CsA + 90 days & $5.4 \pm 0.61$ & $65.07 \pm 0.86$ & $29.53 \pm 0.77$ \\
\hline
\end{tabular}

\section{DISCUSSION}

Studies (7-9) on the drug-induced cellular or tissue proliferation have identified and characterized every biologic pathway that can significantly contribute to the understanding of the CsA-induced periodontal alterations. A number of histological and biochemical studies have investigated the changes in tissue composition and cellular function that accompany CsA-induced gingival overgrowth. However, to the best of our knowledge, the CsA-induced 
cementum alterations remain unclear. Previous studies (11-13) suggested that the occurrence and volume of cementum overgrowth are independent on the root surface, molar teeth or age of rats and, dependent partly on the administration time. The present study was designed to evaluate the thickness of cementum and volume density of cementoblasts during and after CsA treatment. The data of the present study demonstrated an increase of cementum thickness, as well as the maintenance of the volumetric density of cementoblasts, therefore suggesting an increased function of these cells in leading to the formation of new cementum. Although the results shown by Ayanoglou (13) suggested that CsA-induced cementum overgrowth depends partly on the administration time, other factors as drug viability (i.e., dose and serum concentration) has to be considerate.

In the present study, $10 \mathrm{mg} / \mathrm{kg}$ body weight/day of CsA was injected subcutaneously. It would be important in future studies to evaluate which baseline or threshold concentration of the drug is required to initiate the cementum overgrowth.

This study showed that the occurrence and increase of cementum thickness are independent on root surface and molar teeth. However, the values obtained from the morphometric analysis showed that cementum increase is more evident in the apical third of the roots. These results are different from those found by Ayanoglou (12,13), who reported that the cementum is deposited mainly on the cervical root third. The results of the present work also revealed that cementum growth was smaller in older rats. On the other hand, Ayanoglou and Lesty (12) suggested that cementum deposition can not be associated with age-related growth because the increased cementum thickness reported previously $(18,19)$ occurred in remarkably older rats.

The cementum of rats treated with CsA was characterized by its large volume, irregular outline and the rather infrequent observation of incremental lines. The histological findings of the present study are similar to those of a previous study (11), which showed that the deposited cementum was characterized by presenting greater thickness, irregular outline and globular body content. However, in the present study, no globular body content was observed.

It has been shown that CsA not only blocks the immune system by means of inhibition of signaling though cell receptor, but also stimulates the production of TGF- $\beta 1$ (1-3). This potent CsA effect on TGF- $\beta 1$ transcription and secretion has been observed in vitro in human $\mathrm{T}$ lymphocytes, mouse proximal tubular cell lines and tubulointerstitial fibroblasts (1-3) and in vivo in mouse and rat kidneys. Increased TGF- $\beta$ production has recently been demonstrated in CsA-induced gingival overgrowth $(2,4)$. TGF- $\beta 1$ is a multifunctional peptide that regulates diverse biologic activities including cell growth, cell death or apoptosis, cell differentiation and extracellular matrix synthesis (1-3). TGF- $\beta$ overproduction due to CsA may be one of the mechanisms that could explain the greater cementum formation.

Unlike gingival overgrowth or other side effects of CsA, such as nephrotoxicity and hepatoxicity, hypertrichosis, visual discords, paresis or disorientation, new cementum is maintained on a long-term basis after the interruption of CsA therapy. The reasons for this fact might be related to the particular status of cementum characterized by the absence of a real turnover with alternating periods of apposition and resorption (13). In summary, the results of this work showed that cementum overgrowth did not undergo regression after cessation of CsA treatment and this effect can be important information for endodontic treatment purposes of CsAtreated patients. The outcomes of this study also suggest that morphological and molecular investigations, both in vivo and in vitro, are required to have a better understanding of the mechanisms involved in CsAinduced cementum overgrowth.

\section{RESUMO}

Ciclosporina A (CsA) é um potente imunossupressor usado no transplante de órgãos e no tratamento de várias doenças autoimunes. Recentes estudos têm demonstrado que a CsA estimula a deposição de cemento na superfície radicular. O objetivo deste estudo foi de avaliar a espessura do cemento periapical e largura do forame apical em ratos tratados com CsA. Os ratos pesavam $50 \mathrm{~g}$ e foram tratados com doses diárias de $10 \mathrm{mg} / \mathrm{kg}$ de peso corporal de CsA no período de 60 dias. O cemento do primeiro molar inferior foi examinado histologicamente e morfometricamente por análises de cortes em parafina com $5 \mu \mathrm{m}$ de espessura no sentido vestíbulo-lingual e corados com hematoxilina e eosina. As análises histométricas e estereológicas revelaram a presença de largos depósitos de cemento em todas as superfícies radiculares, particularmente maior na região periapical e obliterando o forame. A densidade volumétrica dos cementoblastos não foi aumentada. No período de 5 a 90 dias após o término da terapia com CsA, não houve redução na espessura do cemento. Estes resultados sugerem que o depósito de cemento não é reversível após o tratamento com CsA ser cessado. 


\section{REFERENCES}

1. Serkova N, Christians U. Transplantation: toxicokinetics and mechanisms of toxicity of cyclosporin and macrolides. Curr Opin Investig Drugs 2003;4:1287-1296.

2. Smith JM, Nemeth TL, McDonald RA. Current immunosuppressive agents: efficacy, side effects and utilization. Pediatr Clin North Am 2003;50:1283-1300.

3. Dunn CJ, Wagstaff AJ, Perry CM, Plosker GL, Goa KL. Cyclosporin An Update Review of the Pharmacokinetic Properties, clinical efficacy and tolerability of a microemulsion-based formulation (Neoral) in organ transplantation. Drugs 2001;61:1957-2016.

4. Ho S, Clipstone N, Timmermann L, Northrop J, Graef I, Fiorentino D, Nourse J, Crabtree GR. The mechanism of action of cyclosporin A and FK506. Clin Immunol Immunopathol 1996;80:S40-S45.

5. Kehrl JH, Wakefield LM, Roberts AB, Jakowlew S, AlvarezMon M, Derynck R, Sporn MB, Fauci AS. Production of transforming growth factor beta by human $\mathrm{T}$ lymphocytes and its potential role in the regulation of $\mathrm{T}$ cell growth. J Exp Med 1986;163:1037-1050.

6. Roberts AB, Sporn MB. Physiological actions and clinical applications of transforming growth factor-beta (TGF-beta). Growth Factors 1993;8:1-9.

7. Spolidorio LC, Merzel J, Villalba H, Vargas PA, Colleta RD, Almeida OP. Morphometric evaluation of gingival overgrowth and regression caused by cyclosporin in rats. J Periodontal Res 2001;36:384-389.

8. Spolidorio LC, Spolidorio DM, Neves KA, Gonzaga HFS, Almeida OP. Morphological evaluation of combined effects of cyclosporin and nifedipine on gingival overgrowth in rats. J Periodontal Res 2002;37:192-195.
9. Spolidorio LC, Spolidorio DM, Nassar PO, Nassar CA, Holzhausen M, Almeida OP. Influence of age on combined effects of cyclosporin and Nifedipine on rat alveolar bone. J Periodontol 2004;75:252-256.

10. Erben RG. Skeletal effects of cyclosporin A are gender related in rats. Endocrinology 2003;144:40-49.

11. Ayanoglou CM, Lesty C. Maintenance of new cementum formed during cyclosporin A administration after suspension of the treatment. J Periodont Res 1997;32:614-618.

12. Ayanoglou CM, Lesty C. New cementum formation induced by cyclosporin A: a histological, ultrastructural and histomorphometric study in the rat. J Periodont Res 1997;32:543-555.

13. Ayanoglou CM. Evidence that cyclosporin A administration induces the formation of new cementum-like islets inside the gingival connective tissue. J Periodont Res 1998;33:166171.

14. Ayanoglou CM. Phagocytosis of new cementum-like islets formed inside the gingival connective tissue in cyclosporin A treated rats. J. Periodont Res 1999;34:65-69.

15. Wassef R, Cohen Z, Langer B. Pharmacokinetic profiles of cyclosporine in rats. Influence of rante of administration and dosage. Transplantation 1985;40:489-493.

16. Delesse MA. Procedé mécanique pour determiner la composition des roches. R Acad Sci Paris 1847;25:544-545.

17. Weibel ER. Selection of the best method in stereology. J Microsc 1974;100:261-269.

18. Belting C, Schour I, Weinmann JP, Shepro MJ. Age changes in the periodontal tissues of the rat molar. J Dent Res 1953;32:332-353.

19. Louridis O, Bazopoulou-Kyrkanidou E, Demetriou N. Age effect upon cementum width of albino rat: a histometric study. J Periodontol 1972;43:533-536. 